
World Ecology

\title{
Biological diversity in the coniferous forest on the northern slope of Changbai Mountain, northeast China
}

\author{
Jing Wei , Hongbing Deng , Gang Wu \& Jingzhu Zhao
}

To cite this article: Jing Wei , Hongbing Deng , Gang Wu \& Jingzhu Zhao (2004) Biological diversity in the coniferous forest on the northern slope of Changbai Mountain, northeast China, International Journal of Sustainable Development \& World Ecology, 11:2, 181-190, DOI: 10.1080/13504500409469821

To link to this article: http://dx.doi.org/10.1080/13504500409469821

Published online: 02 Jun 2009.

Submit your article to this journal ¿

Џ Article views: 22

View related articles $₫$

Citing articles: 2 View citing articles ¿ð 


\title{
Biological diversity in the coniferous forest on the northern slope of Changbai Mountain, northeast China
}

\author{
Jing Wei, Hongbing Deng, Gang Wu and Jingzhu Zhao \\ Key Lab of Systems Ecology, Research Center for Eco-Environmental Sciences, \\ Chinese Academy of Sciences, Beijing, P.R. China 100085 \\ Key words: Changbai Mountain, dark coniferous forest, biological diversity
}

\begin{abstract}
SUMMARY
The study focused on the so-called dark coniferous forest belt on the northern slope of Changbai Mountain, at an altitude of 1100 to $1700 \mathrm{~m}$. Forty tree species, 50 shrub species and 165 herb species were recorded in a series of transects. The main impact factors on forest diversity and proposals for sustainable management of this diversity were studied using an altitude and area gradient pattern method. The results showed that the diversity of dark coniferous forest gradually decreased from lower to upper altitude; while the importance value of key species increased. The methodology used to assess attributes for conservation of dark coniferous forest diversity involved measurement of individual trees, number of species, age structure, stand structure, diameter at breast height (DBH), and cumulative wood storage. Different conservation strategies have been developed and are discussed for different parts of the forest.
\end{abstract}

\section{INTRODUCTION}

For terrestrial ecosystems, many modelling experiments have shown that changes in moisture, light and temperature influence plant composition, primary productivity, nutrient cycling (Field et al. 1992; Wray and Strain 1987) and the process and function of ecosystems (Grime 1997; Hooper and Vitousek 1997; Ives et al. 1999; Tilman et al. 1997). Biodiversity is at the heart of productivity and ecosystem sustainable development. Protecting biodiversity is an indispensable part of ecosystem management, involving: (1) maintaining ecosystem processes in temporal and spatial gradients; (2) maintaining the material basis of anti-disturbance and resilience; and (3) adapting to environmental change (Schulze and

Mooney 1993). Biodiversity is a component of the ecological life-support system (the interdependent web of life) that furnishes both natural capital and ecosystem services, both of which are essential to sustainable use of the planet. Some of these components, however, may disappear within the next few generations in areas where accelerated economic growth has brought major environmental challenges. A healthy ecosystem exhibits the attributes of structure, function, complexity, interactions and variation (Vora 1997). Through stability and resilience, ecosystems retain their integrity. They can exist in a variety of conditions, some of them being of natural origin, having evolved through natural succession.

Correspondence: Hongbing Deng, Key Lab of Systems Ecology, Research Center for Eco-Environmental Sciences, Chinese Academy of Sciences, 18 Shuangqing Road, Haidian District, Beijing 100085, China. e-mail: denghb@mail.rcees.ac.cn 
Currently, there is no robust evidence on what level of biodiversity is essential for sustainable use of the planet. Furthermore, not all the species on the planet have yet been discovered and named; and for the many that have been named, their life cycles and habitat requirements are poorly understood. Therefore, conservation projects for biodiversity have been initiated at a greater rate around the world as nations have acknowledged the increasing amount of land degradation and rate of species extinction.

Although ecosystem or conservation management issues can have global, regional or transboundary impacts, most activities need to be focused at the sub-regional and community level to be effective. A functioning and healthy ecosystem can only be achieved through amalgamation of many areas of expertise. Conservation requires maintenance and management of resources over the long term, and allows for natural/stochastic change in ecosystem structure and the natural physical environment. Conservation must consider all components of natural systems (living and non-living parts of the environment), and human systems (culture, society, the built environment) and requires the use of all areas of human expertise (humanities, arts, sciences, engineering) to accomplish its goals. Current conservation movements utilize a more holistic view of ecosystem protection. Recent approaches have considered the concept of sustainable development to be central and have encouraged the survival of all ecosystem components, including physical, biological and human resources. Full integration of all ecosystem components is required if we are to achieve resource sustainability.

This paper analyzes the diversity and preservation of coniferous forest on the northern slope of Changbai Mountain. Although the dark coniferous forest had a wide distribution range on the mountain, past studies have focused mainly on two permanent plots located at 1200 and $1650 \mathrm{~m}$ (Wang et al. 1980; Li and Li 1981; Liu 1997; Chen and Bradshaw 1999). Little effort has previously been made to study conservation mechanisms of coniferous forest diversity with changing elevation. To better understand the distribution and diversity of old-growth coniferous forest on Changbai Mountain, it was important to study such mechanisms throughout this forest zone. This paper reports findings from a new research project, focusing on mechanisms and impact factors that affect the diversity within the coniferous forest on the north slope of Changbai Mountain.

\section{STUDY AREA AND METHODS}

\section{Site description}

Changbai Mountain, on the border between China and North Korea, is the highest mountain on the eastern Eurasian continent, and is an extinct volcano. Changbai Mountain Nature Reserve is the best-preserved forest ecosystem in China, perhaps even in the world and is a designated UNESCO Biosphere Reserve. It is the most representative upland forest ecosystem, containing a range of soils, vegetation, and climate, with distinct altitudinal distributions. The UNESCO Biosphere Reserve protects nearly 200000 ha of natural vegetation and old-growth forest ecosystems. The reserve contains 1337 vascular plant species, including 1250 seed plant species (Xu 1992), and five vegetation zones (Wang et al. 1980; Shao et al. 1996): broadleaf forest (below $700 \mathrm{~m}$ ), broadleaf-coniferous mixed forest (700-1100 m), coniferous forest $(1100-1700 \mathrm{~m})$, birch forest $(1700-2100 \mathrm{~m})$, and tundra (above $2100 \mathrm{~m}$ ) (Figure 1). The coniferous forest zone, also called the dark coniferous forest or spruce-fir forest, is the dominant vegetation type inside the reserve (Li et al. 1994; Shao et al. 1996). The annual mean temperature is $0.9-3.9^{\circ} \mathrm{C}$ and the annual mean rainfall is $600-900 \mathrm{~mm}$.

\section{Sampling design}

Field investigations were carried out in July and August 2000 and 2001. Sample plots were systematically set up using a gradient pattern, at intervals of $100 \mathrm{~m}$, from $1100 \mathrm{~m}$ to $1700 \mathrm{~m}$ on the northern slope of Changbai Mountain(Figure 1). Each plot covered an area of $32 \times 32 \mathrm{~m}$. Within each plot, smaller sampling plots were established at each of the five chosen altitudes. These measured $0.5 \times 0.5 \mathrm{~m}, 1 \times 1 \mathrm{~m}, 2 \times 2 \mathrm{~m}, 4 \times 4 \mathrm{~m}$ and $5 \times 5 \mathrm{~m}$. Measurements made in each plot were: altitude, gradient, canopy density, total shrub coverage, total herb coverage, tree species, tree diameter at breast height (DBH), standing tree vitality, tree height, and the average height of shrubs and herbs. 


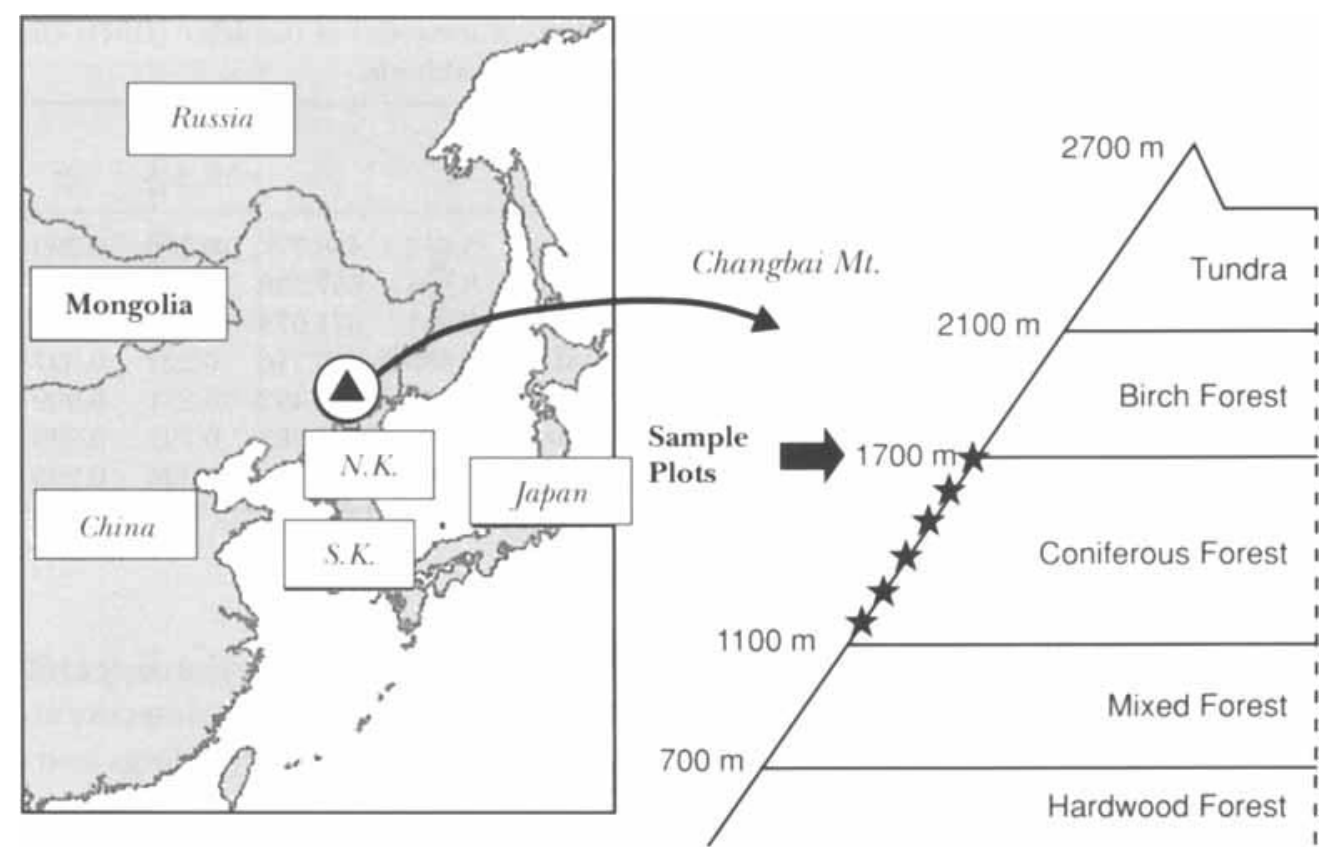

Figure 1 Changbai Mountain, located on the border of China and North Korea, contains five forest vegetation zones. Sample plots were located along a transect extending from 1100 to $1700 \mathrm{~m}$

\section{Data analysis}

Important values were calculated using the following equations:

Relative abundance $=$

$$
\frac{\text { no. of individuals of a species }}{\text { total individuals of all species }} \times 100
$$

Relative frequency $=$

$$
\frac{\text { no. of plots with one species }}{\text { no. of all plots }} \quad \times 100
$$

Relative dominance $=$

$$
\frac{\mathrm{DBH} \text { of one species }}{\mathrm{DBH} \text { of all species }}
$$

Relative coverage $=$

$$
\begin{aligned}
& \frac{\text { coverage of one species }}{\text { total coverage of all species }} \times 100 \\
& \text { Relative abundance }+ \text { Relative frequency } \\
& + \text { Relative dominance } \\
& 3
\end{aligned}
$$

Importance value (shrub, herb) =

Relative height + Relative frequency

+ Relative coverage

$$
3
$$

Diversity index was calculated as:

Biodiversity Shannon index: $\mathrm{H}=-\Sigma \mathrm{P}_{\mathrm{i}} \log \mathrm{P}_{\mathrm{i}}$

Evenness index: $E=H / \ln S$

Ecological dominance index: $\mathrm{D}=\Sigma \mathbf{P}_{\mathrm{i}}{ }^{2}$

$\left(P_{i}\right.$ : importance value of i species, $S$ : total number of species investigated)

\section{RESULTS AND DISCUSSION}

\section{Community composition and diversity}

The nature of the forest ecosystem is determined by topography, distribution and type of vegetation, and community structure. The influence of community type and structure on overall diversity was apparent in the range of different species in the main forest layer and in different layers throughout the altitudinal gradient. Throughout the altitudinal gradient, from 1100$1700 \mathrm{~m}$ asl, coniferous trees dominated the main 
forest layer, while broadleaf tree numbers were much lower. Beneath the main canopy, the species composition of the succession and regeneration layers was basically the same as the upper forest canopy. This demonstrated that most of tree species were naturally regenerating, but individual species, such as larch (Larix olgensis), showed differing regeneration capacity, depending on altitude.

\section{Larix olgensis}

Most larch trees were found in older, singlespecies stands, making up a fixed proportion of the community of the main forest layers. However, few young larch were found in the regeneration layer and, furthermore, there was no renewal, young growth or seedlings below the canopy. This suggests that larch could not regenerate within the forest and was basically receding. Larch is a pioneer species that can rapidly occupy areas following volcanic eruption or fire, creating suitable conditions for forest succession and establishment of other species. As larch is unable to regenerate under the existing forest canopy, it has gradually been replaced by spruce and other conifers. This was very obvious in the experimental plots on Changbai Mountain.

\section{Pinus koraiensis}

Korean pine occupied a different niche from larch. Korean pine seedlings regenerated only in the core distribution layer (below $1200 \mathrm{~m}$ ), but also grow in the main forest canopy. At 1300 $1400 \mathrm{~m}$, the regeneration frequency and density of pine was little different from that at lower elevations. However, its regeneration capacity at this altitude was lower and it did not make a significant contribution to the main forest layer. At $1400 \mathrm{~m}$, pine seedlings were distributing by chance, while at $1700 \mathrm{~m}$ some pine seedlings can be found but there were few juvenile trees.

\section{Betula ermanii}

Betula ermanii is a high-elevation species. Surprisingly, birch regeneration frequency and plant
Table 1 Parameters of diameter (DBH) class distribution at each altitude

\begin{tabular}{crcccc}
\hline $\begin{array}{c}\text { Elevation } \\
(\mathrm{m})\end{array}$ & \multicolumn{1}{c}{$A_{0}$} & \multicolumn{1}{c}{$a$} & \multicolumn{1}{c}{$b$} & \multicolumn{1}{c}{$R$} & $R^{2}$ \\
\hline 1100 & $\mathbf{3 . 8 4 4}$ & 438.77 & 0.280 & 0.999 & 0.999 \\
1200 & 8.308 & 657.739 & 0.290 & 0.996 & 0.991 \\
1300 & 12.411 & 671.078 & 0.340 & 0.993 & 0.986 \\
1400 & 3.430 & 460.716 & 0.224 & 0.997 & 0.993 \\
1500 & 4.231 & 236.493 & 0.251 & 0.999 & 0.999 \\
1600 & 5.187 & 281.285 & 0.795 & 0.999 & 0.997 \\
1700 & 7.287 & 201.61 & 0.426 & 0.995 & 0.989 \\
\hline
\end{tabular}

amount in its core distribution belt $(1600 \mathrm{~m})$ was much lower than that in the non-core area. There were a large number of seedlings and few adult birch below $1600 \mathrm{~m}$, but few seedlings and juvenile trees in its core distribution area. This may possibly be related to its 'old stem to grow roots', as described by Liu (1989).

\section{Community diameter and diversity}

Analysis of standing tree DBH distribution produced an inverted J-shaped curve (not shown). There were many seedlings $<1.3-\mathrm{m}$ high (no chest diameter) and juvenile trees with a DBH $<8 \mathrm{~cm}$. A large decrease occurred between the succession layer $(\mathrm{DBH}<8 \mathrm{~cm})$ and main forest layer $(\mathrm{DBH}>8 \mathrm{~cm})$, while the margin gradually decreased with the increase in DBH. The relationship between standing tree and DBH could be expressed by an exponential attenuation equation:

$\mathrm{N}=\mathrm{A}_{\mathrm{O}}+\mathrm{ae}^{(-\mathrm{bD})}$

where $\mathrm{D}$ is $\mathrm{DBH}, \mathrm{N}$ is trees at relative $\mathrm{DBH}$, and $A_{O}$, $a$ and $b$ are parameters yet to be estimated. DBH of the community assumed an inverted J form (not shown) and, using the exponential attenuation equation, a goodness-of-fit test gave an $R^{2}$ of $>0.9$ (Table 1). Regenerating seedlings $(\mathrm{DBH}<4 \mathrm{~cm})$ and young trees $(\mathrm{DBH}=4-8 \mathrm{~cm})$ were predominant. As DBH increased, the number of standing trees was reduced. This relationship demonstrated that the communities were regenerating well at different elevations on the northern slope of Changbai Mountain, and that they were in a steady state (Liu 1989). 


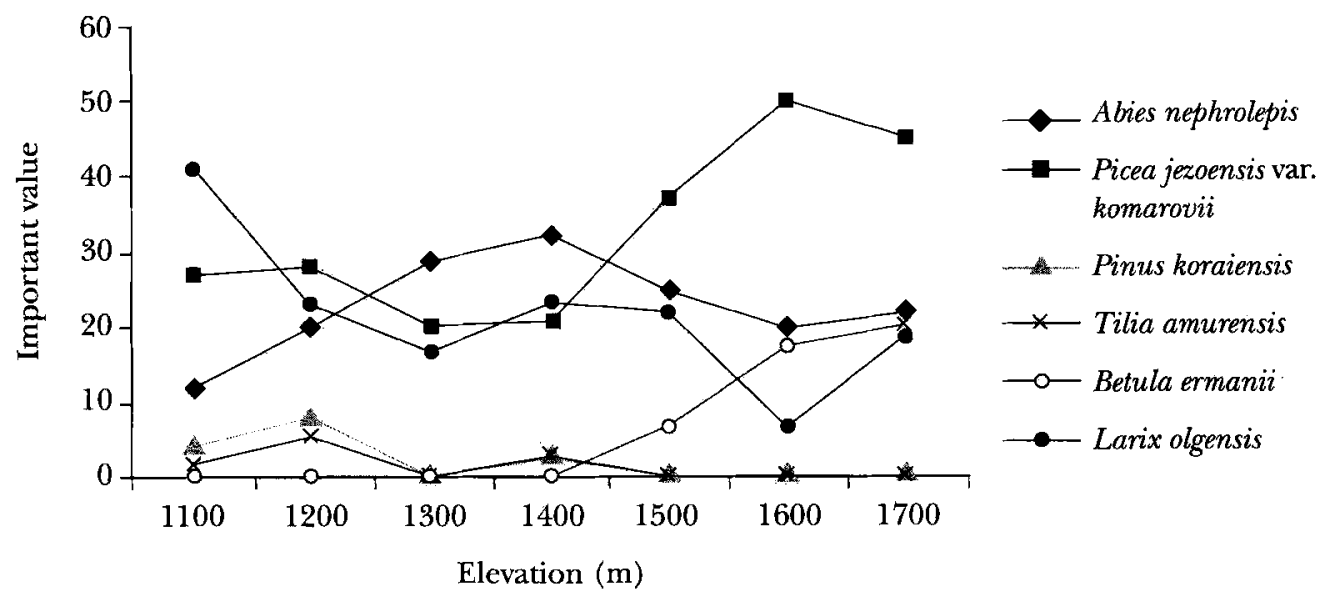

Figure 2 Change in importance values of key species along an elevational gradient

\section{Significant changes in key tree species with elevation}

On the basis of analysis of individual numbers of key tree species in the main forest, succession and regeneration layers, it was possible to understand species regeneration and development strategies.

Abies nephrolepis and Picea jezoensis var komarovii had a large number of individuals in the main forest, succession and regeneration layers, suggesting a healthy and prosperous species structure. In their core distribution area (1100$1700 \mathrm{~m}$ asl), the frequency almost reached $100 \%$, depending on altitude. The importance value gradually increased from $1100 \mathrm{~m}$ to $1400 \mathrm{~m}$, reaching a maximum of 30 at $1400 \mathrm{~m}$ and then gradually decreasing. While the importance value of Picea jezoensis var. komarrovii gradually increased from $1100 \mathrm{~m}$ to $1600 \mathrm{~m}$, reaching a maximum of 45 at $1600 \mathrm{~m}$ and then decreasing. Both tree species played an important role in the forest vegetation and make up $20 \%$ of communities at most elevations (Figure 2).

The importance value of Larix olgensis was about 20 , from lower elevation to the treeline, and reached median values at 1100 to $1700 \mathrm{~m}$, where their frequency reached $100 \%$. This demonstrated that the species had special and strong suitability for their habitat.

Below $1500 \mathrm{~m}$ Pinus koraiensis and Tilia amurensis had a high distribution frequency, but the importance values were less than 10 , reaching zero above $1500 \mathrm{~m}$ (Figure 2).
The frequency of Betula ermanii almost reached $100 \%$ at $1500-1700 \mathrm{~m}$ except in places where the vegetation had been disturbed. Betula ermanii entered the main forest layer at $1500 \mathrm{~m}$, its importance increased with increase in elevation. It was the only species to form a dominant singlespecies community.

The other tree species had more specific elevational niches. They were similar to Pinus koraiensis and showed K strategy species features, where numbers of regenerating trees was low but the quality of such trees entering the main forest layer was high.

\section{Diversity analysis of trees, shrubs and herbs at different altitudes}

Trees constitute the main body of the forest ecosystem, and their diversity and pattern determines ecosystem structure. Tree seedling germination, survival and maturation are influenced by competition, not only from other species but also by competition for resources such as light and water. The microhabitat formed by organisms also influences tree survival and growth. Analysis of diversity of trees growing at different elevations provides an insight into the adaptability of trees under different conditions and their regeneration capacity and success. Table 2 provides a quantitative index of different tree species in the various layers and at different elevations, showing that abundance and diversity of species greatly decreased with increasing altitude. There were 
Table 2 Diversity index of tree species in each layer at each altitude

\begin{tabular}{|c|c|c|c|c|c|c|}
\hline $\begin{array}{l}\text { Elevation } \\
(\mathrm{m})\end{array}$ & Layer & Numbers & Species & $\begin{array}{c}\text { Shannon } \\
\text { index } H\end{array}$ & $\begin{array}{c}\text { Evenness } \\
\text { index }\end{array}$ & $\begin{array}{c}\text { Dominance } \\
\text { index }\end{array}$ \\
\hline \multirow[t]{3}{*}{1100} & Can. & 69 & 9 & 1.388 & 0.631 & 0.3174 \\
\hline & Suc. & 202 & 12 & 1.821 & 0.733 & 0.2037 \\
\hline & Reg. & 430 & 11 & 1.960 & 0.817 & 0.1748 \\
\hline \multirow[t]{3}{*}{1200} & Can. & 107 & 10 & 1.666 & 0.724 & 0.2637 \\
\hline & Suc. & 297 & 10 & 1.431 & 0.621 & 0.3126 \\
\hline & Reg. & 653 & 12 & 1.956 & 0.787 & 0.1565 \\
\hline \multirow[t]{3}{*}{1300} & Can. & 127 & 10 & 1.831 & 0.795 & 0.2188 \\
\hline & Suc. & 261 & 9 & 1.357 & 0.617 & 0.3356 \\
\hline & Reg. & 666 & 8 & 1.778 & 0.855 & 0.1955 \\
\hline \multirow[t]{3}{*}{1400} & Can. & 88 & 7 & 1.415 & 0.727 & 0.3239 \\
\hline & Suc. & 277 & 7 & 1.257 & 0.646 & 0.3174 \\
\hline & Reg. & 459 & 9 & 1.618 & 0.736 & 0.2396 \\
\hline \multirow[t]{3}{*}{1500} & Can. & 76 & 5 & 1.387 & 0.862 & 0.2780 \\
\hline & Suc. & 124 & 6 & 1.291 & 0.720 & 0.3184 \\
\hline & Reg. & 235 & 7 & 1.123 & 0.577 & 0.4213 \\
\hline \multirow[t]{3}{*}{1600} & Can. & 58 & 5 & 1.151 & 0.715 & 0.3989 \\
\hline & Suc. & 32 & 4 & 0.927 & 0.669 & 0.4414 \\
\hline & Reg. & 265 & 5 & 1.393 & 0.866 & 0.2847 \\
\hline \multirow[t]{3}{*}{1700} & Can. & 76 & 5 & 1.128 & 0.701 & 0.4228 \\
\hline & Suc. & 63 & 5 & 1.045 & 0.649 & 0.4674 \\
\hline & Reg. & 201 & 7 & 1.450 & 0.745 & 0.2743 \\
\hline
\end{tabular}

Table 3 Diversity index of tree species at each altitude from importance value

\begin{tabular}{cccccc}
\hline $\begin{array}{c}\text { Elevation } \\
(\mathrm{m})\end{array}$ & $\begin{array}{c}\text { Number of } \\
\text { individuals }\end{array}$ & $\begin{array}{c}\text { Number of } \\
\text { species }\end{array}$ & $\begin{array}{c}\text { Shannon } \\
\text { index }(H)\end{array}$ & $\begin{array}{c}\text { Evenness } \\
(E)\end{array}$ & $\begin{array}{c}\text { Dominance } \\
(D)\end{array}$ \\
\hline 1100 & 701 & 13 & 2.057 & 0.802 & 0.1637 \\
1200 & 1057 & 14 & 1.995 & 0.756 & 0.1628 \\
1300 & 1054 & 12 & 1.871 & 0.753 & 0.1897 \\
1400 & 824 & 10 & 1.586 & 0.689 & 0.2469 \\
1500 & 435 & 9 & 1.357 & 0.618 & 0.3247 \\
1600 & 355 & 6 & 1.416 & 0.791 & 0.2722 \\
1700 & 340 & 7 & 1.345 & 0.691 & 0.3238 \\
\hline
\end{tabular}

nine tree species in the main forest canopy at $1100 \mathrm{~m}$ but only five species at $1700 \mathrm{~m}$. Succession and regeneration were, respectively, 12 and 11 species at $1100 \mathrm{~m}$ and five and seven species at $1700 \mathrm{~m}$. The diversity index determined in layers of the communities changed from 1.4-1.96 at $1100 \mathrm{~m}$ to $1.0-1.45$ at $1700 \mathrm{~m}$. The abundance of trees in layers below $1300 \mathrm{~m}$ was higher than that at $1300 \mathrm{~m}$. The diversity index determined among communities was less obvious below $1700 \mathrm{~m}$ because of lower homogeneity of communities at lower elevations. Generally, the diversity and evenness indexes were much higher in the main forest layer than in regeneration and succession layers at the lower altitudes. However, the diversity and evenness indexes were higher in the regeneration layer than in the main forest and succession layers. The diversity index of each layer was generally less obvious, which showed that communities at different altitudes developed evenly and constituted healthily developing communities.

A similar pattern was found among shrub species as that among the tree species. There were nine shrub species at $1100 \mathrm{~m}$ and eight at $1700 \mathrm{~m}$ (Table 4). The herbs were the most abun- 
Table 4 Diversity index of shrub and herb species

\begin{tabular}{|c|c|c|c|c|c|c|c|c|}
\hline \multirow{2}{*}{$\begin{array}{l}\text { Elevation } \\
\text { (m) }\end{array}$} & \multicolumn{4}{|c|}{ Shrubs } & \multicolumn{4}{|c|}{ Herbs } \\
\hline & Species & $H$ & $E$ & $D$ & Species & $H$ & $E$ & $D$ \\
\hline 1100 & 9 & 1.926 & 0.877 & 0.1721 & 32 & 3.117 & 0.899 & 0.0587 \\
\hline 1200 & 8 & 1.971 & 0.948 & 0.1514 & 22 & 2.714 & 0.878 & 0.1013 \\
\hline 1300 & 7 & 1.783 & 0.916 & 0.1940 & 25 & 2.910 & 0.904 & 0.0690 \\
\hline 1400 & 8 & 1.868 & 0.899 & 0.1880 & 39 & 3.275 & 0.894 & 0.0528 \\
\hline 1500 & 8 & 1.982 & 0.953 & 0.1505 & 59 & 3.656 & 0.897 & 0.0358 \\
\hline 1600 & 4 & 1.172 & 0.845 & 0.3630 & 39 & 3.245 & 0.886 & 0.0533 \\
\hline 1700 & 8 & 1.615 & 0.777 & 0.2627 & 40 & 3.386 & 0.918 & 0.0444 \\
\hline
\end{tabular}

dant group at each altitude. Their abundance peaked at $1500 \mathrm{~m}$ (Table 4). An altitude of 1400 $1500 \mathrm{~m}$ was a transition zone from upland middle dark coniferous forest to upland lower dark coniferous forest. (Li et al. 1994). In comparison with the tree and shrub layers, herb distribution was more even, changing only slightly with altitude. This showed that herbs coexisted in similar proportions at each altitude.

\section{The preservation of forest diversity on Changbai Mountain}

During this investigation, over 40 tree species were recorded, belonging to 12 families and 21 genera; $\mathbf{5 0}$ shrub species, from 16 families and 30 genera; and 165 herb species, from 46 families and 121 genera. The dark coniferous forest is characterized by tall, straight trees, with thick stems (in the case of spruce and fir), a dense canopy and multi-generation compound crown, giving rise to moist or wet woodland. Beneath the forest canopy there were abundant plants including bryophytes, shrubs and herbs.

Under the forest canopy there were many 1-3-year-old fir and spruce seedlings which require shade for establishment but were so dense that many were suppressed or died. Only where trees in the upper layer either died naturally or had been blown down by the wind was there a forest window that allowed some regeneration. The uneven-aged fir forest, with compound layers, was much stronger than the spruce forest. This showed that there was a mutual relationship among tree species in terms of illumination utilization in time and space and that mixed forest is advantageous to natural regeneration. Natural spruce-fir forest constituted a stable vegetation zone formed over the long term. The success of this mixed forest is influenced by man-made fire, other humaninfluenced forms of destruction or changes in climate. Once destroyed, succession proceeds through the initial phases of establishment of poplar and birch trees.

From the summit down, the dark coniferous forest was divided into alpine forest, top mountain land, middle mountain land and lower mountain land. The major stand tree species in each area of dark coniferous forest were Picea jezoensis, Abies nephrolepis and Picea koraiensis. The forest composition did not differ in horizontal distribution.

\section{Diversity of alpine forest}

At $1700 \mathrm{~m}$, the alpine spruce-fir forest was associated with Betula ermanii. This zone is known as the ecologically staggered area. The high elevation is associated with poor soil and very cold temperatures, forming a special and strange landscape. It is the highest place for dark coniferous forest in northeast China and the forest stand structure of spruce-fir had changed greatly in recent years. The age range of the Picea jezoensis and Abies nephrolepis trees in this zone was similar to that in other areas. Twenty-year-old Picea jezoensis made up $3.5 \%$ of the tree population, reaching $37 \%$ for 80 -year-old trees, then decreasing with increasing tree age. Abies nephrolepis 100year-old trees reached a peak value of $32 \%$. Betula ermanii and Larix olgensis in this zone also have a reasonable age distribution. 


\section{Diversity in higher mountain lands}

The forest on brown coniferous soils in the higher mountain zone, between 1600-1700 m, is subject to a cool and wet climate. Picea jezoensis is better adapted to this climate than Abies nephrolepis, which was sparse, while Larix olgensis grew well, and other broadleaf trees were mostly replaced by Betula ermanii. More and older trees of Picea jezoensiswere found here than in the lower forest belts. Mixed age Picea jezoensis was found throughout, most were 20 years old, with 355 ind./ha, making up $25 \%$ of the zone, and decreasing in trees over 40 years old. Individuals of $A$. nephrolepis reached $190 \mathrm{ind}$./ ha, making up $13.5 \%$ of the forest at 120 years old, then decreasing with increasing age. While 20-year-old $A$. nephrolepis made up $11 \%$ and 40 -year-old trees made up $22 \%$ or 145 ind./ha. The DBH of Picea jezoensis and Abies nephrolepis and their individual numbers were normally distributed: DHB of $8 \mathrm{~cm}$ making up $9.2 \%$, DHB of $22 \mathrm{~cm}$ accounting for $11.8 \%$, decreasing thereafter with increasing DBH.

Generally, Picea jezoensis occupied a larger proportion of the zone, dominating the main forest layer (I) and constituting 60 or $70 \%$ overall. This was followed by Larix olgensis and Betula ermanii in terms of cumulative wood storage and individual numbers. The succession (II) and regeneration (III) layers were mainly composed of Picea jezoensis and Abies nephrolepis. In layer I the plant number was 380 ind./ha, making up 32\% of the total with a DBH of 26-46 cm (maximum $62 \mathrm{~cm}$ ) with an accumulation of $70 \%$ and 440 ind./ha. In layers II and III plant number occupied over $65 \%$ (810 ind./ha), but storage increase is only $30 \%$ (180 ind./ha). Overall, the number of trees in a stand was $1200 \mathrm{ind} . / \mathrm{ha}$, with a canopy density of 0.92 and a wood storage of $620 \mathrm{~m}^{3}$.

\section{Diversity in the central mountain land}

This zone is found at elevations of $1400-1500 \mathrm{~m}$. The age structure of Betula costata forest in this zone was the same as in the Korean pine forest. Twenty-year-old Picea jezoensis made up $41 \%$ of the forest and 240 ind./ha, reducing with increasing tree age. Forty-year-old Abies nephrolepis constituted $53 \%$ of the zone and 480 ind./ha, again reducing with tree age. The DBH change of Picea jezoensis and Abies nephrolepis was similar to that of Pinus koraiensis. Generally, there were more trees with a DBH of $8 \mathrm{~cm}$ : Abies nephrolepis $(27.7 \%)$ and Picea asperata (21.4\%). Above $10 \mathrm{~cm}$ $\mathrm{DBH}$, the plant number decreased with increasing DBH, but Abies nephrolepis and Picea jezoensis had more plants with $18 \mathrm{~cm}$ and $32 \mathrm{~cm} \mathrm{DBH}$ before decreasing with increasing DBH.

\section{Diversity in the lower mountain land}

The lower mountain land at $1100-1300 \mathrm{~m}$ is a transition belt from mixed coniferous-broadleaf forest to dark coniferous forest. The terrain slopes gently, drainage is good and the soil is deep. Besides Picea jezoensis and Abies nephrolepis, there was mixed growth of Pinus koraiensis, $P$. sylvestriformis and Larix olgensis, forming a complex stand. Pinus koraiensis was found below the dark coniferous forest and provided suitable conditions for growth of many broadleaved trees. Layer I contained mainly Picea jezoensis (mean DBH $36 \mathrm{~cm}$, height $24 \mathrm{~m}$ ) and $P$. sylvestriformis (mean DBH $38 \mathrm{~cm}$, height $22 \mathrm{~m}$ ), while Pinus koraiensis (mean DBH $42 \mathrm{~cm}$ ) was also present. In layer II, Abies nephrolepis was dominant, with 90 ind./ha, and Pinus koraiensis and P. sylvestriformis had large cumulative wood storage of $36 \mathrm{~m}^{3} / \mathrm{ha}$ and $33 \mathrm{~m}^{3} / \mathrm{ha}$. In layer III Abies nephrolepis was the main component $(80 \%)$, with a density of 1632 ind./ ha and cumulative wood storage of $457.6 \mathrm{~m}^{3} / \mathrm{ha}$. Beneath the forest canopy there was good natural regeneration.

\section{CONCLUSIONS}

The diversity of dark coniferous forest on Changbai Mountain is mainly related to altitude, plant population and community composition, $\mathrm{DBH}$ structure of the community, and relative importance value of each species. The diversity gradually decreased from lower to upper altitudes, from thin to thick DBH, from small to large relative dominance or importance value of dominant tree species. The conservation mechanisms for forest diversity are related to elevation, individual number of species, age structure, forest stand structure, diameter at breast height and cumulative storage. 
The forest was typical of boreal forest, from species composition to population and community structure. Regeneration, distribution frequency and importance value of the key species change greatly with altitude, becoming less complex with increasing altitude. Pinus koraiensis, Betula costata, Larix olgensis and Betula ermanii trended from complicated to simple forest with increasing altitude. The most common species were Larix olgensis, Betula ermanii and Betula costata. The basic species were mainly Picea jezoensisvar. komarovii and Abies nephrolepis. These two species gradually increased in number with increasing altitude, and the frequency of Picea jezoensis var. komarovii approached $70 \%$. However, the individual number of Abies nephrolepis changed in opposition to Picea jezoensis var. komarovii, while individual tree numbers of the two species were almost the same at $1720 \mathrm{~m}(678$ ind./ha Picea jezoensisvar. komarovii and 680 ind./ ha Abies nephrolepis), showing that species composition was subject to climate, soil, altitude, and rainfall.

There were many seedlings and young trees in the understorey. The seedlings of Abies nephro- lepis (DBH 2-8 cm) approximated to 680 ind./ ha, and seedlings of Picea jezoensis var. komarovii approximated to $790 \mathrm{ind}$./ ha at $1500 \mathrm{~m}$, showing good natural regeneration of the dark coniferous forest. However, mortality was high in seedlings and juvenile trees and it may be necessary to establish seedling nurseries on Changbai Mountain to improve forest stand diversity and enhance regeneration capacity. In order to preserve diversity of dark coniferous forest in Changbai Mountain, some disturbance should be introduced to create gaps for natural regeneration. Such gap disturbance has always been the main driver of natural dark coniferous forest regeneration on Changbai Mountain.

\section{ACKNOWLEDGEMENTS}

The authors would like to thank all partner members and institutions. This project was supported by the National Natural Science Foundation of China (No: 39970591) and key project KIP Chinese Academy of Sciences (KZCX3-SW-423).

\section{REFERENCES}

Chen J and Bradshaw GA. Forest structure in space: a case study of an old growth spruce-fir forest in Changbai Natural Reserve. Forest Ecology E $M a n-$ agement, 1999;120(1-3):219-33

Field CB, Chapin FS III, Matson PA and Mooney HA. Responses of terrestrial ecosystems to approach. Ann Rev Ecol Systematics, 1992;23:201-36

Grime JP. Biodiversity and ecosystem function: the debate deepens. Science, 1997;277:1260-1

Hooper DU and Vitousek PM. The effects of plant composition and diversity on ecosystem processes. Science, 1997;277:1302-5

Ives AR, Gross K and Klug JL. Stability and variability in competitive communities. Science, 1999;286:5 $42-4$

Li WH, Deng K and Shao B. A study of basic feature and community structure in dark coniferous forest of Changbai Mountain. Research on Forest Ecosystems, 1994;7:1-15 (in Chinese)

Li WH and Li F. Study of biomass and primary production of the main ecosystems on Changbai Mountain. Research on Forest Ecosystems, 1981;2: 34-50 (in Chinese)
Liu QJ.A dynamic study on Betula ermanii on Changbai Mountain. PhD thesis, Applied Ecology Institute, Chinese Academy of Sciences, Shenyang; 1989

Liu QJ. Structure and dynamics of the subalpine coniferous forest on Changbai Mountain, China. Plant Ecology, 1997;132:97-105

Schulze ED and Mooney HA. Biodiversity and Ecosystem Function. Springer-Verlag; 1993

Shao G, Zhao G, Zhao S, Shugart HH, Wang S, and Schaller J. Forest cover types derived from landsat TM imagery for Changbai Mountain Area of China. Can. J. For. Res, 1996;26:206-16

Tilman D, Knops J and Wedin D. The influences of functional diversity and composition on ecosystem processes. Science, 1997;277:1300-2

Vora R. Developing programs to monitor ecosystems health and effectiveness of management practices on lakes states national forests. Biological Conservation, 1997;80:289-302

Wang Z, Xu Z, Li X, Dai H and Zhang Y. The main forest types and their features of community struc-ture on northern slope of Changbai Mountain. Research on Forest Ecosystems, 1980;1:25-42 (in Chinese) 
Wray SM and Strain BR. Competition on old-field perennials under $\mathrm{CO}_{2}$ enrichment. Ecology, 1987; 68:1116-20
Xu Z. A periodic summary of the research on forest ecosystems on Changbai Mountain. Research on Forest Ecosystems, 1992;6:1-13 (in Chinese) 